\title{
Evaluation of Biological Activities of Fermented Hizikia fusiformis Extracts
}

\author{
Seong Hwan Park ${ }^{1}$, Sol Jee Lee ${ }^{2}$, MyeongJeong Jeon ${ }^{3}$, Seo-Yeon Kim ${ }^{3}, \mathrm{Ok}_{-} \mathrm{Ju} \mathrm{Mun}^{3}$, Mihyang Kim ${ }^{3}$, \\ Chang-Suk Kong ${ }^{3}$, Dong-Geun Lee ${ }^{1,2}$, Ki Hwan Yu ${ }^{4}$, Yuck Young Kim ${ }^{4}$ and Sang-Hyeon Lee ${ }^{1,2 *}$ \\ ${ }^{1}$ Department of Bioscience and Biotechnology, Graduate School, Silla University, Busan 617-736, Korea \\ ${ }^{2}$ Department of Pharmaceutical Engineering Silla University, Busan 617-736, Korea \\ ${ }^{3}$ Department of Food and Nutrition, Silla University, Busan 617-736, Korea \\ ${ }^{4}$ IS Food Co., Marine Bio-industry Department Center, Busan, 619-912, Korea
}

Received February 7, 2014 /Revised March 17, 2014 /Accepted March 19, 2014

\begin{abstract}
Antioxidative, immunostimulating, and antihypertensive activities of hot water extracts of fermented Hizikia fusiformis were evaluated. Fermentation with lactic acid bacteria generally increased the biological activities of $H$. fusiformis. Fermentation with isolated Weissella sp. SH-1 resulted in 13.83-62.15\% DPPH radical scavenging activity and $34.90-59.25 \%$ SOD-like activity. The maximal inhibition of ACE was $82.25 \%$, and the maximal reduction in NO production was $46.53 \%$. Fermentation with Lactobacillus casei resulted in $11.98-72.84 \%$ DPPH radical scavenging activity and 14.17-33.62\% of SOD-like activity. The maximal inhibition of ACE was $73.31 \%$, and the maximal reduction in NO production was $65.20 \%$. These results hint at the applicability of fermentation with lactic acid bacteria to improve the diverse biological activities of $H$. fusiformis and to develop functional materials or foods.
\end{abstract}

Key words : Antihypertension, antioxidation, fermentation, Hizikia fusiformis, immunostimulation

\section{서 론}

우리나라는 바다를 옆에 두는 지형을 가지고 있으며, 약 750 여 종의 해조류가 분포한다고 보고되어 있다. 그 중 극히 일부 분인 30 여종을 식용으로 소비하거나, 식품첨가물이나 공업용 다당류의 원료 또는 비료 및 사료의 원료 등으로 이용하고 있다. 최근에는 해양생물자원 유래의 기능성 천연 생리활성물 질에 대한 관심이 지속적으로 높아지고 있으며, 해양 동물 유 래의 생리활성물질뿐만 아니라 해조류 유래의 생리활성물질 이 영양적인 측면은 물론 각종 질병의 치료 및 건강 유지 등에 도움이 된다는 많은 연구결과가 지속적으로 보고되고 있는 실정이다 $[5,13,17]$.

해조류 중 하나인 갈조류에는 톳(Hizikia fusiformis), 미역 (Undaria pinnatifida), 다시마(Laminaria japonica), 모자반(Sargassum fulvellum) 등이 있으며, 이들은 항암활성 $[6,19]$ 과 angiotensin-I converting enzyme (ACE) 저해와 관련된 고혈압 억제 활성을 갖는 것으로 알려져 있다[5]. 톳은 혈액응고 및 면역증강 작용을 나타낸다고 알려진 기능성 다당류를 많이 함유하고 있으며[25], 톳 추출물에 대해서는 항균, 항산화, 항

\footnotetext{
*Corresponding author

Tel : +82-51-999-5624, Fax : +82-51-999-5636

E-mail : slee@silla.ac.kr

This is an Open-Access article distributed under the terms of the Creative Commons Attribution Non-Commercial License (http://creativecommons.org/licenses/by-nc/3.0) which permits unrestricted non-commercial use, distribution, and reproduction in any medium, provided the original work is properly cited.
}

고지혈, 항콜레스테롤 등의 연구가 보고되어 있다[9, 23].

체내에서 생성된 활성산소종(Reactive oxygen species, $\mathrm{ROS}$ )은 산소의 대사산물로서 정상세포 내 호흡이나 세포질 내 효소 작용 등에 의해 내인성으로 형성되거나 다양한 외부 요소에 의해 형성된다. 이들은 체내의 지질, 단백질, DNA 등 을 손상시켜 세포의 기능을 억제시킬 뿐만 아니라 ROS 발생 이 세포의 항산화 능력을 초과하는 경우 산화적 스트레스에 노출되어 항상성의 불균형을 초래한다[3, 8]. 세포 내의 산화적 손상을 억제시키거나 지연시키는 효소로는 superoxide dismutase (SOD), peroxidase, catalase 등이 있다[10].

$\mathrm{ACE}$ 는 기질인 angiotensin-I을 가수분해하여 angiotensin$\mathrm{II}$ 를 생성하는 효소이며, $\mathrm{ACE}$ 분해산물인 angiotensin-II는 직 접 동맥 및 소동맥을 수축시키고 알도스테론의 유리를 촉진시 켜 혈압을 올림으로써 대표적인 성인병인 고혈압을 유발시키 는데 중요한 역할을 하는 효소이다[24]. 따라서 $\mathrm{ACE}$ 활성을 억제시키는 물질은 angiotensin-II의 생성을 저해하여 고혈압 을 억제하는 작용을 나타내는 것으로 알려져 있다[22].

Nitric oxide $(\mathrm{NO})$ 는 L-arginine을 기질로 하여 Nitric oxide synthase (NOS)에 의해 생성되는 무기 유리체로 lipopoly saccharide (LPS)에 의해 염증을 유도하여 활성화된 세포에서 염증 반응의 중요 매개물질의 $\mathrm{NO}$ 의 생성을 억제하는 원리를 이용하여 측정한다. $\mathrm{NO}$ 는 활성산소 중 하나이며, 염증 유발 에 중요한 역할을 하여 천식, 기관지염, 관절염, 다발성경화증, 동맥경화증, 뇌졸중, 알츠하이머병이나 파킨슨병과 같은 퇴행 성 뇌질환 및 바이러스 감염으로 인한 염증질환을 유발하고, 질환을 악화시킨다[12]. 
톳을 포함한 해조류의 유용성분을 추출하여 이용할 때에는 열수로 직접 추출하거나, 알칼리, 산 또는 효소 등을 처리하여 추출한 후 가공하는 방법들이 대부분이다[11]. 그러나 이러한 추출공정만으로는 해조류에 포함된 성분들을 효과적으로 추 출해내지 못하는 단점을 가지고 있다[25]. 이에 이러한 단점을 극복하기 위하여 최근에는 미생물을 이용하여 해조류를 발효 하려는 시도들이 행해지고 있지만, 해조류 발효 추출물에 대 한 체계적인 생리활성검증에 대한 보고는 미흡한 실정이다.

이에 본 연구에서는 우리나라에 자생하는 대표 갈조류인 톳을 대상으로 2 종의 발효균주를 이용하여 여러 조건에서 발 효를 수행하였으며, 톳 발효물의 열수 추출물에 대한 항산화 활성(DPPH 소거능, SOD), $\mathrm{ACE}$ 저해활성 및 $\mathrm{NO}$ 생성억제 활성 등의 생리활성을 측정하고 비교하였다.

\section{재료 및 방법}

재료

시료

본 실험에 사용한 톳(Hizikia fusiformis)은 파라제주(Jeju, Korea)에서 판매하는 것을 구입하여 사용하였으며, 탈염된 톳 건조물을 초미세 기류식 분쇄기(KMS-200, Korea)로 분쇄한 다음 밀봉하여 $4^{\circ} \mathrm{C}$ 에 보관하면서 사용하였다.

\section{발효균주}

톳을 발효하기 위해 Lactobacillus casei ((주)메디오젠, Jecheon, Korea)와 재래식 물김치에서 직접 분리하고 동정한 Weissella sp. SH-1균을 이용하였다. L. casei와 Weissella sp. SH-1 균주는 유산균 선택배지인 MRS 액체배지(Difco, USA)에 배양하였 고, 멸균된 $80 \%$ glycerol (Duchefa Biochemie, Netherlands)에 배양액을 1:1로 현탁하여 $-80^{\circ} \mathrm{C}$ deep freezer (NF-140SF, HFC, Japan)에서 장기보관하였다.

\section{방법}

\section{재래식 물김치에서의 균주 분리}

재래식 물김치에 존재하는 유산균을 분리하기 위해서 물김 치의 상등액을 멸균수로 희석하여 희석현탁액 $\left(10^{-1} \sim 10^{-3}\right)$ 을 만 든 후 MRS 한천배지에 도말하였다. 도말한 배지는 $30^{\circ} \mathrm{C}$ 배양 기에서 2일간 배양하였으며 형태적인 차이를 보이는 집락을 대상으로 균주를 선별하고 분리하였다.

\section{분리된 균주의 $\mathrm{DNA}$ 추출 및 $16 \mathrm{~S} \mathrm{rRNA}$ 유전자 분석}

분리된 균주를 동정하기 위해서 $16 \mathrm{~S} \mathrm{rRNA}$ 유전자를 분석 하였다. 균주를 MRS 액체배지에 접종하여 $30^{\circ} \mathrm{C}$ 에서 48 시간 배양 후 원심 분리하여 균체를 회수하였다. Wizard Genomic DNA Purification Kit (Promega, Madison, WI, USA)를 사용 하여 회수한 균체에서 총세포 DNA를 분리하였다. $16 \mathrm{~S} \mathrm{rRNA}$ 유전자를 증폭하기 위해서 universal primer인 27F (5'-AGA GTT TGA TCM TGG CTC AG-3')와 1492R (5'-TAG GGH
TAC CTT GTT ACG ACT T-3')을 사용하여, Lee 등[17]의 방 법대로 PCR반응을 수행하였다. 증폭된 PCR 산물은 PCR/Gel Combo Kit (NucleoGen, Siheung, Korea)를 사용하여 정제하 였다. 염기서열 분석은 코스모진텍사(Cosmo Gene Tech, Korea)에 의뢰하였으며, National Center for Biotechnology Information (NCBI, USA)의 BLAST를 사용하여 $16 \mathrm{~S}$ rRNA 유전자 단편의 염기서열의 상동성을 근거로 분리된 균주들을 동정하였다.

\section{발효균주를 이용한 톳 발효액의 제조}

2종의 발효균들(L. casei, Weissella sp. SH-1)은 각각 MRS 액체배지를 이용하여 $30^{\circ} \mathrm{C}$ 에서 정치 배양하였다. Yoo [26]의 방법을 변형하여 $10 \mathrm{~g}$ 의 톳 분말에 $\mathrm{ddH}_{2} \mathrm{O} 190 \mathrm{ml}$ 를 첨가한 후, 탄소원으로 glucose를 $1 \%$ 의 농도로 첨가하였으며, 또한 유기산인 lactate 혹은 citrate를 $0.5 \%$ 의 농도로 첨가한 후, 12 $1^{\circ} \mathrm{C}$ 의 가압 조건에서 30 분간 멸균하였다. 여기에 2 종의 발효 균을 각각 $0.05 \%$ 의 농도로 접종한 후 $30^{\circ} \mathrm{C}$ 배양기에서 30 일간 배양하여 톳 발효액을 제조하였다.

\section{발효 톳 추출물의 제조}

발효가 완료된 톳 발효액을 rotary vacuum evaporator (R-200, Buchi, Switzerland)를 이용하여 농축시킨 후, 동결건 조장치(FD8518, Ilshin BioBase, Korea)를 이용하여 동결건조 하여 발효 톳 건조시료를 얻었다. 건조시료에 각각 10 배량 $(\mathrm{w} / \mathrm{v})$ 의 3 차 증류수를 첨가한 후, $100^{\circ} \mathrm{C}$ 에서 4 시간씩 2회 추출 을 수행하였으며, 추출액을 지름 $150 \mathrm{~mm}$ 의 여과지(Advantec, Japan)를 이용하여 2회 여과한 후, rotary vacuum evaporator 를 이용하여 농축시킨 후, 동결건조하여 추출물을 얻었다. 동 결 건조한 추출물 $10 \mathrm{mg}$ 을 3차 증류수 $1 \mathrm{ml}$ 에 용해한 후, 필터 (pore size $0.20 \mu \mathrm{m}$ filter)로 여과멸균하여 사용하였다.

\section{$\mathrm{DPPH}$ radical 소거활성 측정}

항산화활성의 대표적인 지표인 radical 소거활성(radical scavenging activity)은 Blois [4]의 방법을 변형하여 톳 발효추 출물에 대한 1,1-diphenyl-2-picrylhydrazyl (DPPH)의 전자공 여능으로 측정하였다. 즉, 추출물 $100 \mu \mathrm{l}$ 에 $0.15 \mathrm{mM} \mathrm{DPPH}$ 용액(70\% ethanol에 용해) $100 \mu \mathrm{l}$ 혹은 70\% ethanol $100 \mu \mathrm{l}$ 를 첨가하여 총액의 부피가 $200 \mu \mathrm{l}$ 가 되도록 하였다. 이 반응액을 $37^{\circ} \mathrm{C}$ 에서 30 분 방치한 후 분광광도계(UV/VIS spectrometer, Jasco, Japan)를 사용하여 $520 \mathrm{~nm}$ 에서 흡광도를 측정한 후에, 대조군에 비하여 감소된 흡광도로부터 라디칼 소거율을 계산 하였다. 양성 대조군으로 3,5-di-tert-4-butylhydroxytoluene (BHT, Sigma, USA)를 사용하였다.

\section{Superoxide dismutase (SOD) 유사활성 측정}

Superoxide dismutase 유사활성은 Marklund [20]의 방법 에 따라 측정하였다. 톳 발효추출물 $0.2 \mathrm{ml}$ 에 $0.05 \mathrm{M}$ Tris- $\mathrm{HCl}$ buffer $2.6 \mathrm{ml}$ 과 pyrogallol $0.2 \mathrm{ml}$ 을 넣고 $37^{\circ} \mathrm{C}$ 에서 10 분간 반응을 시킨 다음 $1 \mathrm{~N} \mathrm{HCl} 0.1 \mathrm{ml}$ 를 넣어 반응을 정지시키고 
$420 \mathrm{~nm}$ 에서 흡광도를 측정하였으며, 저해율(\%)은 시료를 첨 가하지 않은 대조군과 비교하여 나타내었다.

\section{Angiotensin-I converting enzyme (ACE) 저해활성 측정}

Angiotensin-I converting enzyme 저해활성 측정은 Cushman과 Ondetti [21]의 방법을 변형하여 수행하였다. 즉, 반응 구는 $0.3 \mathrm{M} \mathrm{NaCl}$ 을 함유하는 $0.1 \mathrm{M}$ sodium borate buffer $(\mathrm{pH}$ 8.3)에 기질로 $25 \mathrm{mM}$ hippuryl-L-histidyl-L-leucine (HHL, Sigma, USA) 용액 $50 \mu 1$ 를 혼합하고 대조군은 발효 톳 추출물 대신 동일 buffer $50 \mu 1$ 를 첨가하여 $37^{\circ} \mathrm{C}$ 에서 30 분간 반응시키 고, $1 \mathrm{~N} \mathrm{HCl} 250 \mu \mathrm{l}$ 의 첨가로 반응을 중지시킨 뒤 ethyl acetate $1.5 \mathrm{ml}$ 를 첨가하였다. Ethyl acetate층만을 취한 다음 용매를 증류시킨 잔사에 $2 \mathrm{ml}$ 의 증류수를 첨가하여 효소에 의해 기질 로부터 분리되어 추출된 hippuric acid를 분광광도계를 사용 하여 $280 \mathrm{~nm}$ 에서 흡광도를 측정한 후에, 가수분해물 첨가 여 부를 다음 식에 따라 백분율로 $\mathrm{ACE}$ 저해활성을 나타내었다.

$\mathrm{ACE}$ 저해활성 $(\%)=(\mathrm{C}-\mathrm{T}) /(\mathrm{C}-\mathrm{B}) \times 100$

$\mathrm{T}$ : 발효 톳 추출물의 흡광도

C: Control (sample 대신 증류수를 넣은 군)의 흡광도

B: Sample 대조군 $(\mathrm{HCl}$ 에 의한 반응정지 후 효소를 넣은 군)의 흡광도

\section{Nitric oxide (NO) 생성 억제능 측정}

Raw 264.7 세포를 96-well plates에 $1 \times 10^{3}$ cells/well로 분주 하여 $37^{\circ} \mathrm{C}, 5 \% \mathrm{CO}_{2}$ incubator에서 $10 \%$ fetal bovine serum (FBS)과 $1 \%$ penicillin이 함유된 Dulbecco's modified Eagle's medium (DMEM, BioWhittaker, USA) 배지로 24시간 동안 배양하였다. 새로운 배지로 교체한 다음 시료를 최종농도50, $100,500,1,000 \mu \mathrm{g} / \mathrm{ml}$ 로 첨가하여1시간 동안 전처리한 후에 NO 생성을 유도하기 위하여 lipopolysaccharide (LPS, final concentration: $1 \mu \mathrm{g} / \mathrm{ml}$ 를 처리하여 $37^{\circ} \mathrm{C}, 5 \% \mathrm{CO}_{2}$ incubator 에서 48시간 동안 배양하였다. 상등액을 Griess reagent (Sigma, USA)와 1:1로 혼합하여 15분 동안 실온에 방치한 후, ELISA Reader (Multiskan GO, Thermo Scientific, Finland)를 이용하
여 $540 \mathrm{~nm}$ 에서 흡광도를 측정한 후에 생성된 $\mathrm{NO}$ 의 양을 계산 하였다.

\section{통계처리}

연구결과로 얻어진 자료는 Macintosh용 통계프로그램인 Aabel 2.0 (Gigawiz Ltd Co., USA)을 이용하여 하위그룹 각각 의 기술 통계치(Mean $\pm \mathrm{SEM}$ )를 산출하였다. 분산분석(ANOVA) 후에 Fisher's PLSD의 다중범위 유의성 검증을 실시하였고, $p<0.05$ 이상의 수준에서 유의성을 검증하였다.

\section{결과 및 고찰}

\section{유산균 분리 및 동정}

한국 재래식 물김치에서 유산균 선택배지인 MRS 배지를 이용하여 약 10,000 개의 세균 군락을 분리하였다. 이 중 9 개의 세균을 순수분리하고 총세포 DNA를 분리하여 $16 \mathrm{~S} \mathrm{rRNA}$ 서 열을 분석하였다. 분석된 염기서열로 기존에 보고되어 있는 염기서열들과의 상동성을 분석한 결과, 9 개의 세균 모두 Weissella 속의 한 종으로 밝혀졌으며, 이중 하나를 Weissella sp. SH-1으로 명명하고 본 연구에 사용하였다(Fig. 1).

유산균은 톳 특유의 냄새를 경감시키면서 유용성분을 증대 시킨다고 보고되어 있어, 최근의 연구에서는 해조류 발효에 유산균을 이용하고 있다[2, 7,25$]$.

\section{톳 발효 추출물의 제조}

해조류 다당 성분의 효소 또는 화학적 분해 처리에 의해 기능성 해조 올리고당이 생성되는 것으로 알려져 있다[26]. 본 연구에서는 톳 시료의 전처리 및 유용성분의 유기산 추출을 위하여 유[26]의 방법을 따라 citrate 혹은 lactate를 첨가한 다 음 가압과 가온을 동시에 수행하였다. 또한 톳에 포함된 다당 을 포함한 유용성분들의 이용성을 높이기 위하여 탄소원으로 포도당을 첨가하여 두 종류의 유산균으로 발효를 수행하였다 [26]. 이를 이용하여 톳 발효 추출물을 제조한 결과, glu-

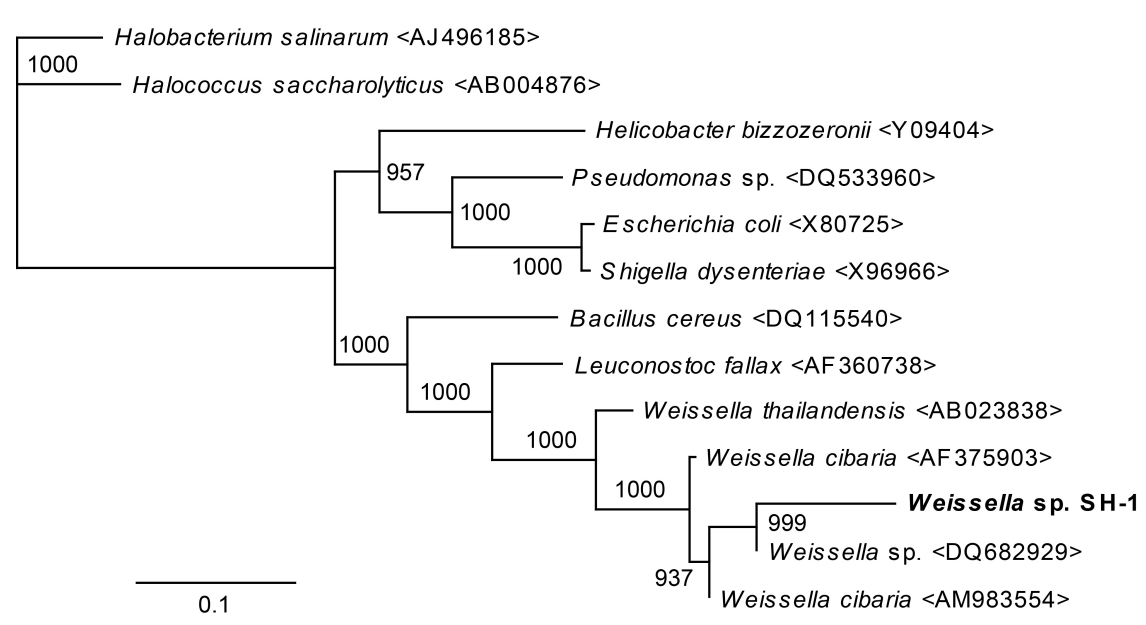

Fig. 1. Phylogenetic tree based on partial 16S rRNA gene sequence of an isolated strain comparing with members of Weissella and other genera. The numbers at the branch nodes are bootstrap values and numbers in each parenthesis are access numbers in NCBI. 
Table 1. Yields (\%) of hot water extracts from fermented Hizikia fusiformis

\begin{tabular}{ccc}
\hline & Conditions & Yields (\%) \\
\hline \multirow{3}{*}{ Glucose } & No seeding & 17.65 \\
& Weissella sp. SH-1 & 18.71 \\
& Lactobacillus casei & 18.18 \\
\hline \multirow{2}{*}{ Glucose } & No seeding & 19.10 \\
+lactate & Weissella sp. SH-1 & 15.38 \\
& Lactobacillus casei & 13.26 \\
\hline \multirow{2}{*}{ Glucose } & No seeding & 18.40 \\
+citrate & Weissella sp. SH-1 & 24.17 \\
& Lactobacillus casei & 25.27 \\
\hline
\end{tabular}

cose+citrate를 첨가한 군에서는 유산균 접종군이 무접종군에 비해 전반적으로 높은 수율을 나타내었다. 특히, glucose+citrate를 첨가한 $L$ case $i$ 혹은 Weissella sp. SH-1 접종군의 추출물 이각각 $25.27 \%$ 및 $24.17 \%$ 로 가장 높은 수율을 보였고, glucose+lactate를 첨가한 L. casei 접종군의 추출물이 $13.26 \%$ 로 가장 낮은 수율을 나타내었다(Table 1).

\section{톳 발효 추출물의 DPPH 전자공여능에 의한 항산화 활성}

전자공여능 측정에 사용된 $\mathrm{DPPH}$ 는 안정한 자유 라디칼로 서, 시료가 항산화 활성을 갖고 있다면, DPPH가 갖고 있는 지질산화에 관여하는 자유 라디칼의 비공유 결합을 소거하여 $\mathrm{DPPH}$ 의 환원성을 높일 것이다[1]. 발효 톳 추출물의 $\mathrm{DPPH}$ 전자공여능을 측정한 결과를 Table 2에 나타내었다. 톳의 발효 여부에 따른 $\mathrm{DPPH}$ 전자공여능을 동일한 첨가물 종류와 농도 에서 비교한 결과는 다음과 같았다. 첫째 전반적으로 추출물 의 농도가 증가할수록 항산화 활성이 증가하였으며, $11.98 \sim 72.84 \%$ 의 활성을 보였다. 둘째 glucose를 첨가한 Weissellasp. SH-1 접종군이 무접종군과 비교했을 때 $1,000 \mu$ $\mathrm{g} / \mathrm{ml}$ 의 농도에서는 $58.53 \%$ 로 통계적으로 유의한 높은 활성차
이를 보였다( $\beta<0.001)$. 셋째 L. casei 접종군은 무접종군에 비해 추출물 $500 \mu \mathrm{g} / \mathrm{ml}$ 이상의 농도에서 전반적으로 통계적으로 유의한 활성차이를 나타냈으며 $500,1,000 \mu \mathrm{g} / \mathrm{ml}$ 에서는 무접 종군에 비해 통계적 유의한 높은 활성 차이를 보였다 $(p<0.05)$. 특히, glucose+lactate를 첨가한 L. casei 접종군의 경우, $500 \mu$ $\mathrm{g} / \mathrm{ml}$ 이상의 농도에서 $50.76 ~ 72.84 \%$ 의 항산화 활성을 나타내 어 무접종군에 비하여 통계적으로 유의한 높은 활성 차이를 보였다 $(p<0.001)$.

Kwak 등[14]은 톳 에탄올 추출물이 투여농도 500 2,500 $\mathrm{gg} /$ $\mathrm{ml}$ 까지의 범위 내에서 $9.5 \%$ 가 가장 높은 항산화 활성으로 나 타나 전반적으로 톳 에탄올 추출물에서 낮은 활성을 보였다. Song 등[25]의 연구에서는 발효하지 않은 톳 추출액이 500 및 $1,000 \mathrm{\mu g} / \mathrm{ml}$ 의 농도에서 각각 $38.96 \%$ 및 $49.12 \%$ 의 항산화 활 성을 나타내었고, Lactobacillus brevis로 발효한 톳 발효액의 항 산화 활성은 각각 $52.82 \%$ 및 $67.51 \%$ 로 유산균 발효에 의한 활성 증가를 보였다. 본 연구에서는 500 및 $1,000 \mu \mathrm{g} / \mathrm{ml}$ 의 농 도에서 $30.49 \sim 72.84 \%$ 의 항산화 활성을 보였고, 특히 glucose+ lactate를 첨가한 L. casei 접종군은 각각 $50.76 \%$ 및 $72.84 \%$ 로 높은 항산화 활성을 보였다( $p<0.001)$.

\section{톳 발효 추출물의 SOD 유사활성에 의한 항산화 활성}

$\mathrm{SOD}$ 는 생체내에서 $\mathrm{O}_{2}^{-}$(superoxide) 소거에 관여하는 효소 로서 생성된 활성 산소는 생체 내에서 산화적 장애를 초래하 게 된다. 발효 톳 추출물의 SOD 유사활성을 이용한 항산화 활성을 측정한 결과를 Table 3에 나타내었다. 톳의 발효 여부 에 따른 SOD 유사활성을 동일한 첨가물의 종류와 농도에서 비교한 결과는 다음과 같았다. 첫째 전반적으로 추출물의 농 도가 증가할수록 SOD 유사활성이 증가하였으며, 10.8 59.2\% 의 활성을 보였다. 둘째 Weissella sp. SH-1 접종군이 무접종군 에 비해 추출물 $100 \mathrm{\mu g} / \mathrm{ml}$ 이상의 농도에서 통계적으로 좋은 활성을 보였으며 $500,1,000 \mathrm{\mu g} / \mathrm{ml}$ 에서는 무접종군에 비해 높

Table 2. DPPH radical scavenging activities of hot water extracts from fermented Hizikia fusiformis

\begin{tabular}{|c|c|c|c|c|c|}
\hline \multicolumn{2}{|c|}{ Sample concentrations $(\mu \mathrm{g} / \mathrm{ml})$} & 50 & 100 & 500 & 1,000 \\
\hline \multicolumn{2}{|c|}{ BHT } & $56.33 \pm 2.46$ & $75.29 \pm 3.98$ & $89.98 \pm 0.95$ & $91.40 \pm 0.82$ \\
\hline \multirow{3}{*}{ Glucose } & No seeding & $14.83 \pm 1.67$ & $17.28 \pm 1.03$ & $37.46 \pm 0.63$ & $40.81 \pm 3.46$ \\
\hline & Weissella sp. SH-1 & $13.83 \pm 1.24$ & $16.43 \pm 1.42$ & $38.83 \pm 1.40$ & $58.53 \pm 0.58^{m+k+x}$ \\
\hline & Lactobacillus casei & $11.98 \pm 1.64$ & $16.52 \pm 0.85$ & $31.00 \pm 2.10^{*}$ & $50.19 \pm 2.50^{\text {th }}$ \\
\hline \multirow{3}{*}{$\begin{array}{l}\text { Glucose } \\
\text { +lactate }\end{array}$} & No seeding & $15.26 \pm 0.42$ & $16.21 \pm 0.88$ & $36.78 \pm 0.86$ & $55.65 \pm 1.72$ \\
\hline & Weissella sp. SH-1 & $19.58 \pm 1.38$ & $16.23 \pm 3.82$ & $37.44 \pm 0.25$ & $62.15 \pm 8.67$ \\
\hline & Lactobacillus casei & $17.15 \pm 0.64$ & $19.12 \pm 1.03$ & $50.76 \pm 1.07^{\text {tht }}$ & $72.84 \pm 4.53^{\text {whtex}}$ \\
\hline \multirow{3}{*}{$\begin{array}{l}\text { Glucose } \\
\text { +citrate }\end{array}$} & No seeding & $15.57 \pm 0.78$ & $18.58 \pm 1.06$ & $32.76 \pm 6.48$ & $36.68 \pm 1.29$ \\
\hline & Weissella sp. SH-1 & $19.85 \pm 1.50$ & $13.69 \pm 1.22$ & $30.49 \pm 1.32$ & $42.41 \pm 4.30$ \\
\hline & Lactobacillus casei & $14.49 \pm 0.57$ & $17.52 \pm 0.22$ & $36.51 \pm 2.57$ & $54.43 \pm 3.24^{\text {thxt }}$ \\
\hline
\end{tabular}

Mean \pm SEM for three tests are shown as DPPH radical scavenging activity (\%). ANOVA with Fisher's PLSD post-hoc test $p<0.05^{*}$, $p<0.01^{* *}, p<0.001^{* * *}$ were compared with no seeding. This experiment was repeated at least twice yielding reproducible results. BHT: 3,5-di-tert-4-butylhydroxytoluene. 
Table 3. SOD like activity of hot water extracts from fermented Hizikia fusiformis

\begin{tabular}{cccccc}
\hline \multicolumn{2}{c}{ Sample concentrations $(\mu \mathrm{g} / \mathrm{ml})$} & 50 & 100 & 500 & 1,000 \\
\hline \multirow{3}{*}{ Glucose } & No seeding & $12.00 \pm 0.84$ & $18.73 \pm 1.85$ & $29.25 \pm 2.18$ & $34.76 \pm 1.03$ \\
& Weissella sp. SH-1 & $10.81 \pm 1.11$ & $12.19 \pm 1.26^{*}$ & $16.95 \pm 1.54^{* * *}$ & $27.31 \pm 4.11^{* * *}$ \\
& Lactobacillus case & $12.81 \pm 0.71$ & $20.61 \pm 1.65$ & $27.65 \pm 0.93$ & $26.92 \pm 2.40^{* *}$ \\
\hline \multirow{2}{*}{ Glucose } & No seeding & $23.56 \pm 1.14$ & $33.68 \pm 1.28$ & $47.70 \pm 2.07$ & $50.55 \pm 1.12$ \\
+lactate & Weissella sp. SH-1 & $34.90 \pm 1.61^{* *}$ & $44.42 \pm 1.10^{* *}$ & $53.96 \pm 1.61^{* *}$ & $59.25 \pm 3.37^{* * *}$ \\
& Lactobacillus case & $14.17 \pm 1.73^{* *}$ & $18.03 \pm 0.91^{* * *}$ & $28.55 \pm 3.65^{* * *}$ & $33.62 \pm 1.90^{* * *}$ \\
\hline \multirow{2}{*}{ Glucose } & No seeding & $10.88 \pm 0.35$ & $18.41 \pm 0.59$ & $28.79 \pm 1.31$ & $41.39 \pm 3.02$ \\
+citrate & Weissella sp. SH-1 & $17.53 \pm 0.41^{*}$ & $26.87 \pm 1.01^{*}$ & $27.85 \pm 2.23$ & $35.29 \pm 3.27^{*}$ \\
& Lactobacillus casei & $26.99 \pm 2.94^{* * *}$ & $26.29 \pm 2.96^{*}$ & $31.00 \pm 3.09$ & $32.25 \pm 1.52^{* *}$ \\
\hline
\end{tabular}

Mean \pm SEM for three tests are shown as SOD like activity. ANOVA with Fisher's PLSD post-hoc test $p<0.05^{*}, p<0.01^{* *}, p<0.001^{* * *}$ were compared with no seeding. This experiment was repeated at least twice yielding reproducible results.

은 통계적 유의성을 보였다( $\beta<0.05)$. 특히, glucose+lactate를 첨가한 Weissella sp. SH-1 접종군의 경우, 34.9 59.2\%의 SOD 유사활성을 나타내어 무접종군에 비하여 모든 추출물 농도에 서 통계적으로 유의한 높은 활성을 보였다 $(p<0.05)$. 셋째 $L$. casei 접종군은 무접종군과 비교했을 때, 전반적으로 통계적으 로 유의한 SOD 유사활성의 개선을 나타내지 않았으나, glucose+ citrate 첨가군의 경우에는 $100 \mathrm{\mu g} / \mathrm{ml}$ 까지의 낮은 추출 물 농도에서는 통계적으로 유의한 SOD 유사활성의 개선을 보였다 $(p<0.05)$.

Lee [16]는 톳 에탄올 추출물에 대한 SOD 유사활성을 보고 하였는데 $1,000 \mathrm{\mu g} / \mathrm{ml}$ 의 농도에서 $18.4 \%$ 의 낮은 활성을 보였 다. Song 등[25]의 연구에서는 발효하지 않은 톳 추출액이 500 및 $1,000 \mathrm{\mu g} / \mathrm{ml}$ 의 농도에서 각각 $32.11 \%$ 및 $37.62 \%$ 의 $\mathrm{SOD}$ 유사활성을 나타내었고, Lactobacillus brevis로 발효한 톳 발효 액의 SOD 유사활성은 각각 $37.99 \%$ 및 $44.67 \%$ 로 유산균 발효 에 의한 억제 활성 증가를 보였다. 본 연구에서는 500 및 1,000 $\mu \mathrm{g} / \mathrm{ml}$ 의 농도에서 $16.95 \sim 59.25 \%$ 의 SOD 유사활성 개선을 보 였고, 특히 glucose+lactate를 첨가한 Weissella sp. SH-1 접종 군은 각각 $53.96 \%$ 및 59.25\%로 높은 SOD 유사활성을 보여
( $\propto<0.05)$, 분리 균주가 톳의 SOD 유사활성을 증진시킨다는 사 실을 확인할 수 있었다.

\section{톳 발효 추출물의 ACE 저해활성에 의한 항고혈압 활성}

톳 발효 추출물의 고혈압관련 효소인 $\mathrm{ACE}$ 의 저해 활성을 측정한 결과를 Table 4 에 나타내었다. 톳의 발효 여부에 따른 $\mathrm{ACE}$ 저해 활성을 동일한 첨가물 종류와 농도에서 비교한 결 과는 다음과 같았다. 첫째 전반적으로 추출물의 농도가 증가 할수록 $\mathrm{ACE}$ 저해활성이 증가하였으며 추출물의 농도가 50 , $100,500 \mathrm{\mu g} / \mathrm{ml}$ 에서는 양성 대조군인 captopril과 유사하거나 높은 활성을 보였다. 둘째 Weissella sp. SH-1 접종군이 glucose, glucose+lactate, glucose+citrate 등의 모든 첨가군에서 전반적으로 가장 좋은 활성을 보였으며 $500,1,000 \mu \mathrm{\mu g} / \mathrm{ml}$ 에서 는 무접종군에 비해 높은 통계적 유의성을 $(p<0.001)$ 보였다. 셋째 glucose+citrate를 첨가한 Weissella sp. SH-1 접종군이 발 효 추출물 $1,000 \mu \mathrm{g} / \mathrm{ml}$ 농도에서 $82.25 \%$ 의 ACE 저해활성을 보였으며 무접종군에 비해 약 1.4 배 높은 활성을 보였다. 넷째 L. casei 접종군을 무접종군과 비교했을 때, glucose 첨가군에 서는 모든 추출물 농도에서 유의적인 효과가 없었고 glu-

Table 4. ACE inhibitory activities (\%) of hot water extracts from fermented Hizikia fusiformis under various concentrations

\begin{tabular}{|c|c|c|c|c|c|}
\hline \multicolumn{2}{|c|}{ Sample concentrations $(\mu \mathrm{g} / \mathrm{ml})$} & 50 & 100 & 500 & 1,000 \\
\hline \multicolumn{2}{|c|}{ Captopril } & $21.12 \pm 0.83$ & $24.04 \pm 0.35$ & $58.96 \pm 0.40$ & $94.42 \pm 0.83$ \\
\hline \multirow{3}{*}{ Glucose } & No seeding & $42.02 \pm 1.08$ & $45.50 \pm 1.21$ & $44.43 \pm 0.71$ & $53.08 \pm 1.71$ \\
\hline & Weissella sp. SH-1 & $44.43 \pm 0.46$ & $49.51 \pm 0.46$ & $60.21 \pm 0.56^{* * *}$ & $68.78 \pm 1.55^{* * *}$ \\
\hline & Lactobacillus casei & $39.18 \pm 2.32$ & $39.71 \pm 3.52$ & $45.42 \pm 0.61$ & $53.52 \pm 0.93$ \\
\hline \multirow{3}{*}{$\begin{array}{l}\text { Glucose } \\
\text { +lactate }\end{array}$} & No seeding & $38.54 \pm 0.41$ & $38.89 \pm 0.09$ & $54.06 \pm 1.93$ & $57.90 \pm 1.24$ \\
\hline & Weissella sp. SH-1 & $36.66 \pm 3.27$ & $60.57 \pm 2.20^{\text {*** }}$ & $68.60 \pm 1.43^{* * *}$ & $72.26 \pm 6.17^{* * *}$ \\
\hline & Lactobacillus casei & $35.59 \pm 0.70$ & $40.64 \pm 1.28$ & $50.07 \pm 0.96$ & $73.31 \pm 2.79^{* * * *}$ \\
\hline \multirow{3}{*}{$\begin{array}{l}\text { Glucose } \\
\text { +citrate }\end{array}$} & No seeding & $36.49 \pm 0.99$ & $42.28 \pm 0.16$ & $51.74 \pm 0.09$ & $59.05 \pm 0.79$ \\
\hline & Weissella sp. SH-1 & $27.83 \pm 0.31^{*}$ & $48.62 \pm 8.97$ & $69.58 \pm 0.67^{* * *}$ & $82.25 \pm 1.39^{* * *}$ \\
\hline & Lactobacillus casei & $32.14 \pm 2.48$ & $34.93 \pm 1.62^{*}$ & $51.39 \pm 1.61$ & $62.15 \pm 3.40$ \\
\hline
\end{tabular}

Mean \pm SEM for three tests are shown as ACE inhibitory activity. ANOVA with Fisher's PLSD post-hoc test $p<0.05^{*}, p<0.01^{* *}, p<0.001^{\star * *}$ were compared with no seeding. This experiment was repeated at least twice yielding reproducible results. 
Table 5. Effects of hot water extracts from fermented Hizikia fusiformis on intracellular NO level in LPS-stimulated Raw 264.7 cells

\begin{tabular}{|c|c|c|c|c|c|}
\hline \multicolumn{2}{|c|}{ Sample concentrations $(\mu \mathrm{g} / \mathrm{ml})$} & 50 & 100 & 500 & 1,000 \\
\hline \multirow{3}{*}{ Glucose } & No seeding & $142.88 \pm 2.69$ & $138.37 \pm 5.01$ & $93.66 \pm 0.41$ & $58.40 \pm 1.23$ \\
\hline & Weissella sp. SH-1 & $145.26 \pm 4.34$ & $107.30 \pm 1.31^{* \star \star}$ & $110.52 \pm 0.38^{\text {knt }}$ & $62.63 \pm 1.83$ \\
\hline & Lactobacillus casei & $116.97 \pm 1.61^{* * *}$ & $123.41 \pm 3.04^{* * *}$ & $90.48 \pm 4.12$ & $34.80 \pm 1.07^{\text {*k* }}$ \\
\hline \multirow{3}{*}{$\begin{array}{l}\text { Glucose } \\
\text { +lactate }\end{array}$} & No seeding & $95.80 \pm 1.97$ & $85.58 \pm 3.90$ & $85.18 \pm 1.57$ & $63.09 \pm 0.77$ \\
\hline & Weissella sp. SH-1 & $97.68 \pm 2.01$ & $101.06 \pm 2.43^{\star * *}$ & $73.96 \pm 0.45^{* *}$ & $56.58 \pm 0.27^{*}$ \\
\hline & Lactobacillus casei & $100.53 \pm 0.97$ & $95.44 \pm 2.68^{* *}$ & $84.36 \pm 1.86$ & $60.43 \pm 2.14$ \\
\hline \multirow{3}{*}{$\begin{array}{l}\text { Glucose } \\
\text { +citrate }\end{array}$} & No seeding & $87.41 \pm 2.87$ & $91.26 \pm 3.67$ & $72.67 \pm 0.94$ & $65.66 \pm 0.51$ \\
\hline & Weissella sp. SH-1 & $86.84 \pm 1.94$ & $84.57 \pm 1.41^{*}$ & $74.07 \pm 0.44$ & $53.47 \pm 0.05^{* *}$ \\
\hline & Lactobacillus casei & $86.47 \pm 1.38$ & $87.51 \pm 1.09$ & $76.65 \pm 0.40$ & $61.30 \pm 0.77$ \\
\hline
\end{tabular}

The cells were pretreated with hot water extracts from fermented Hizikia fusiformis and following by treating with LPS $(1 \mu \mathrm{g} / \mathrm{ml})$ for $48 \mathrm{hr}$. The nitrite content of culture media was analyzed. Mean \pm SEM for three tests are shown as nitrite content (\%) compared with no sample treatment as $100 \%$. ANOVA with Fisher's PLSD post-hoc test $p<0.05^{*}, p<0.01^{* *}, p<0.001^{* * *}$ were compared with no seeding. This experiment was repeated at least twice yielding reproducible results.

cose+lactate 첨가군에서는 추출물 $1,000 \mu \mathrm{g} / \mathrm{ml}$ 의 농도에서만 유의적인 $(p<0.001) \mathrm{ACE}$ 저해활성이 관찰되었다.

Lee 등[15]은 해조류를 다양한 온도에서 열수추출을 수행하 고 추출물의 $\mathrm{ACE}$ 저해활성을 비교하였는데 $70^{\circ} \mathrm{C}$ 의 열수추출 물이 가장 높은 저해활성을 보였으며 해조류에 따라 7.0 $10.9 \%$ 의 저해활성을 나타내었고 톳의 경우 $7.5 \%$ 였다. Cha 등 [5]은 녹조류와 갈조류 추출물의 $\mathrm{ACE}$ 저해활성을 보고하였는 데 추출온도에 따라 $200 \mathrm{\mu g} / \mathrm{ml}$ 의 농도에서 $0.3 \sim 62.5 \%$ 의 저해 활성을 나타냈으며 톳의 경우 21.8 42.1\%였다. 본 연구에서는 glucose+lactate 첨가군에서 Weissella sp. SH-1 접종군이 100 $\mathrm{\mu g} / \mathrm{ml}$ 이상의 농도에서 $\mathrm{ACE}$ 활성을 $60 \%$ 이상 저해하여 $(p \ll 0.001)$ 기존 보고들에 비해 활성이 높았다.

\section{톳 발효 추출물의 NO 생성 억제능에 의한 항염증 활성 측정}

염증유발에 중요한 역할을 하는 $\mathrm{NO}$ 생성 억제능을 측정한 결과를 Table 5에 나타내었다. 톳의 발효 여부에 따른 NO 생 성 억제능을 동일한 첨가물 종류와 농도에서 비교한 결과는 다음과 같았다. 첫째 전반적으로 추출물의 농도가 증가할수록 $\mathrm{NO}$ 생성 억제능이 증가하였다. 둘째 glucose+lactate를 첨가 한 Weissella sp. SH-1 접종군에서 500 1,000 $\mu \mathrm{g} / \mathrm{ml}$ 농도의 추 출물이 $26.04 \sim 3.44 \%$ 의 억제능을 나타내었고, 무접종군과 비 교한 결과 통계적으로 유의한 억제능 증가를 보였다( $p<0.05)$. 셋째 glucose+citrate를 첨가한 Weissella sp. SH-1 접종군에서 $100 \sim 1,000 \mathrm{\mu g} / \mathrm{ml}$ 농도의 추출물이 $15.43 \sim 46.53 \%$ 의 억제능을 나타내었고, 무접종군과 비교한 결과 통계적으로 유의한 억제 능 증가를 보였다 $(p<0.05)$. 넷째 L. casei 접종군은 무접종군과 비교했을 때, 전반적으로 통계적으로 유의한 $\mathrm{NO}$ 생성 억제능 의 향상을 나타내지 않았으나, glucose 첨가군의 경우에는 $1,000 \mathrm{\mu g} / \mathrm{ml}$ 의 추출물 농도에서는 통계적으로 유의한 가장 높은 값인 $65.20 \%$ 의 $\mathrm{NO}$ 생성 억제능을 보였다 $(p<0.05)$.

Song 등[25]은 유산균 발효에 의한 톳 추출액의 항염증 활 성을 보고하였는데, 발효하지 않은 톳 추출액의 $\mathrm{NO}$ 생성 억제
효과는 $500,1,000 \mu \mathrm{g} / \mathrm{ml}$ 의 농도에서 각각 $3.80 \%$ 및 $14.69 \%$ 였 으며, 유산균 톳 발효액의 NO 생성 억제 효과는 각각 $11.34 \%$ 및 $21.95 \%$ 로 유산균 발효에 의한 억제 활성 증가를 보고하였 다. 본 연구에서는 glucose를 첨가한 L. casei 접종군에서는 50, $100,1,000 \mu \mathrm{g} / \mathrm{ml}$ 에서 무접종군에 비해 NO 생성 억제 효과가 통계적으로 확인되었다( $p<0.001)$. 특히 $1,000 \mu \mathrm{g} / \mathrm{ml}$ 의 농도에 서 glucose를 첨가한 L. casei 접종군에 $65.20 \%$ 로 높은 $\mathrm{NO}$ 생 성 억제 효과를 보였다.

\section{감사의 글}

본 연구는 교육과학기술부와 한국연구재단의 지역혁신인 력양성사업으로 수행된 연구결과이며 이에 감사드립니다(No. NRF-2013H1B8A2032201).

\section{References}

1. Ancerexicz, J., Migliavacca, E., Carrupt, P. A., Testa, B., Bree, F., Zini, R., Tillnent, J. P., Labidalle, S., Guyot, D., ChauventMonges, A. M., Crevat, A. and Le Ridant, A. 1998. Structure property relationships of trimetazidine derivivatives and model compounds as potential antioxidants. Free Radical Bio Med 25, 113-120.

2. Bae, H. N. and Kim, Y. M. 2010. Improvement of the functional qualities of sea tangle extract through fermentation by Aspergillus oryzae. Korean J Fish Aquat Sci 13, 12-17.

3. Beckman, B. K. and Ames, B. N. 1998. The free radical theory of aging matures. Physiol Rev 78, 547-581.

4. Blois, M. S. 1958. Antioxidant determination by the use of a stable free radical. Nature 26, 1199-1200.

5. Cha, S. H., Ahn, G. N., Heo, S. J., Kim, K. L., Lee, K. W., Song, C. B., Cho, S. K. and Jeon, Y. J. 2006. Screening of extracts from marine green and brown algae in Jeju for potential marine angiotensin-I converting enzyme (ACE) inhibitory activity. J Korean Soc Food Sci Nutr 35, 307-314. 
6. Cho, K. J., Lee, Y. S. and Ryu, B. H. 1990. Antitumor effect and immunology activity of seaweeds toward Sarcoma-180. J Korean Food Sci Nutr 23, 345-352.

7. Eom, S. H., Lee, B. J. and Kim, Y. M. 2010. Effect of yeast fermentation on the antioxidant and antiinflammatory activity of sea tangle water extract. Korean J Fish Aquat Sci 43, 117-124.

8. Halliwell B. and Gutteridge, J. M. 1986. Oxygen free radicals and iron in relation to biology and medicine: some problems and concepts. Arch Biochem Biophys 246, 501-514.

9. Jang, S. E. and Chyun, K. H. 2007. Effects of dietary calcium level and Hizikia fusiforme supplementation on bone indices and serum lipid levels in ovariectomized rats. J Korean Soc Food Sci Nutr 40, 419-427.

10. Jung, S., Kim, H. W. and Yoon, S. 1999. Analysis of antioxidant nutrients in green yellow vegetable juice. J Food SCi Biotech 31, 880-886.

11. Kim, H. S. and Bae, T. J. 2002. Studies on the hydrolysis of seaweed using microorganisms and its application. $J$ Korean Food Sci Nutr 35, 438-444.

12. Kim, Y. J. and So, D. Y. 2012. Antioxidant and inhibitory effects of Korean Panax ginseng extract on pro-inflammatory mediators in LPS-stimulated RAW264.7 macrophages. $J$ Korean Soc Food Sci Nutr 41, 1371-1377.

13. Kim, Y. M., Kim, D. S. and Choi, Y. S. 2004. Anticoagulant activities of brown seaweed extracts in Korea. Korean J Food Sci Technol 36, 1008-1013.

14. Kwak, C. S., Kim, S. A. and Lee, M. S. 2005. The correlation of antioxidative effects of 5 Korean common edible seaweeds and total polyphenol content. J Korean Soc Food Sci Nutr 34, 1143-1150.

15. Lee, H. O., Kim, D. S., Do, J. R. and Ko, Y. S. 1999. Angiotensin-I converting enzyme inhibitory of algae. $J$ Korean Soc Food Sci Nutr 32, 427-431.

16. Lee, H. R. 2007. Antioxidant and antitumor activites of crude extracts by Hizikia fusiformis. MS Thesis. Dong-A University.

17. Lee, I. K. and Gang, S. W. 1986. A check list of marine algae in Korea. Algae 2, 311-325.

18. Lee, Y. J., Kim, B. K., Lee, B. H., Jo, K. I., Lee, N. K., Chung, C. H., Lee, Y. C. and Lee, J. W. 2008. Purification and characterization of cellulase produced by Bacillus amyoliquefaciens DL-3 utilizing rice hull. Bioresour Technol 99, 378-386.

19. Lee, Y. S., Kim, D. S., Ryu, B. H. and Lee, S. H. 1992. Antitumor and immunomodulating effects of seaweeds toward Sarcoma-180 cell. J Korean Food Sci Nutr 21, 544-550.

20. Marklund, S. and Marklund, G. 1974. Involvement of the superoxide anion radical in the oxidation of pyrogallol and a convenient assay for superoxide dismutase. Eur J Biochem 47, 469-474.

21. Ondetti, M. A. and Cushman, D. W. 1982. Enzymes of the renin-angiotensin system and their inhibitors. Ann ReV Biochem 51, 283-308.

22. Ondetti, M. A., Rubin, B. and Cushman, D. W. 1977. Design of specific inhibitors of angiotensin. Science 196, 441-444.

23. Park, K. E., Jang, M. S., Kim, C. W., Kim, Y. K., Seo, Y. W. and Park, H. Y. 2005. Antioxidant activity on ethanol extract from boiled-water of Hizikia fusiformis. J Korean Soc Appl Biol Chem 48, 435-439.

24. Ryu, S. K. 2000. The effect of the renin-angiotensin-aldosterone systemgene polymorphism on coronary in-stent. MS Thesis. Yonsei University.

25. Song, H. S., Eom, S. H., Kang, Y. M., Choi, J. D. and Kim, Y. M. 2011. Enhancement of the antioxidant and anti-inflammatory activity of Hizikia fusiforme water extract by latic acid bacteria fermentation. Korean J Fish Aquat Sci 44, 111-117.

26. Yoo, K. H. 2000. Deodorization of seaweed product off-flavors by lactic acid bacteria fermentation. MS Thesis. Kangnung National University.

\section{초록 : 톳 발효 추출물의 생리활성 검증}

$$
\begin{aligned}
& \text { 박성환 }^{1} \cdot \text { 이솔지 }{ }^{2} \cdot \text { 전명정 }^{3} \cdot \text { 김서연 }^{3} \cdot \text { 문옥주 }^{3} \cdot \text { 김미향 }^{3} \cdot \text { 공창숙 }^{3} \cdot \text { 이동근 }^{1,2} \cdot \text { 유기환 }^{4} \cdot \text { 김육용 }^{4} \cdot \text { 이상현 }^{1,2 *} \\
& \left({ }^{1} \text { 신라대학교 일반대학원 생명 공학과, }{ }^{2}{ }^{\text {신라대학교 제약공학과, }}{ }^{3}{ }^{\text {신라대학교 식품영 양학과, }}{ }^{4}(\text { 주 })\right. \text { 아이에스 푸드) }
\end{aligned}
$$

톳에 포함된 기능성 성분들의 효율적인 이용을 위하여 갈조류인 톳의 건조분말에 Lactobacillus casei와 Weissella sp. SH-1을 각각 접종하여 $30^{\circ} \mathrm{C}$ 에서 한 달 동안 발효를 수행하였으며, 발효 톳의 열수 추출물을 제조하여 항산화 활성, 면역활성 및 항고혈압활성을 측정하였다. 그 결과, 전반적으로 유산균 발효가 톳의 생리활성을 개선한다는 사실을 확인할 수 있었다. Weissellasp. SH-1 접 종군은 $13.83 ~ 62.15 \%$ 의 DPPH radical 소거활성, 34.9 59.2\%의 SOD 유사활성, 최대 $82.25 \%$ 의 ACE 저해활성, 최대 $46.53 \%$ 의 NO 생성 억제활성을 보였다. 또한, L. casei 접종군은 11.98 72.84\% 의 DPPH radical 소거활성, $14.17 \sim 33.62 \%$ 의 SOD 유사활성, 최대 $73.3 \%$ 의 $\mathrm{ACE}$ 저해활성, 최대 $65.20 \%$ 의 NO 생성 억제활성을 보였다. 본 연구결과로, 유산균을 이용한 톳의 발효를 통해 생리활성물질의 이용 성이 높아진 것으로 확인되어 이를 이용한 기능성 소재 및 식품의 개발이 가능할 것으로 기대된다. 